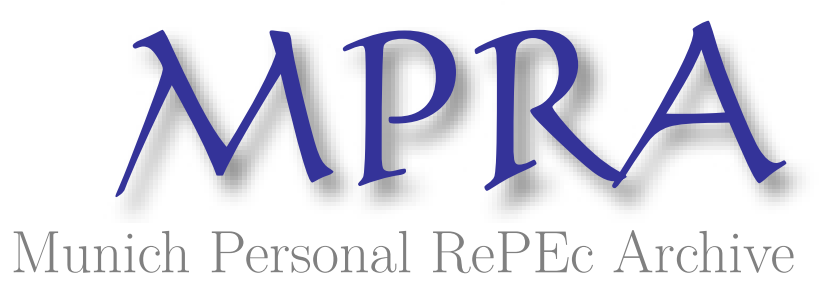

\title{
The effect of social trust on achievement test performance of students in Japan
}

Yamamura, Eiji

10 November 2010

Online at https://mpra.ub.uni-muenchen.de/26699/

MPRA Paper No. 26699, posted 15 Nov 2010 14:20 UTC 


\title{
The effect of social trust on achievement test performance of students in Japan
}

\section{Eiji Yamamura*}

Department of Economics, Seinan Gakuin University, 6-2-92 Sawara-ku, Nishijin, Fukuoka 814-8511, Japan

\begin{abstract}
Empirical results using Japanese data suggest that social trust improves student language and mathematics achievement test scores in primary and junior high school. After controlling for endogeneity bias, social trust had a greater effect on scores for primary school students than on scores for junior high school students.
\end{abstract}

Keywords: Social trust, human capital

JEL classification: H5, I21.

${ }^{*}$ Tel: 81-92-823-4543, Fax: 81-92-823-2506

E-mail address: cyl02111@nifty.com 


\section{Introduction}

It is widely known that social capital plays an important role in improving economic efficiency and thus economic development (Knack and Keefer 1997). In his seminal work, Coleman (1988) was the first to argue that social capital leads to human capital formation. Coleman categorized social capital into trustworthiness of the social environment, information flow capability of the social structure, and norms accompanied by sanctions. However, various proxies for social capital seem to play different roles (Bjørnskov 2006; Paldam 2000). Therefore, it is necessary to define social capital more rigorously. Recent works have defined social capital as social trust and have examined the effect of social trust on education (Bjørnskov 2009; Papagapitos and Riley 2009; Yamamura 2010). Papagapitos and Riley (2009) suggested that social trust enhances secondary school enrollment. Bjørnskov (2009) indicated that social trust leads to growth of schooling. However, little is known about the effect of social trust on the performance of students ${ }^{1}$. From an economic viewpoint, it is necessary to explore how and the extent to which social trust influences student performance because the return on investment in education is important.

In Japan, nationwide achievement tests are conducted in primary and junior high school. Subtests include mathematics and Japanese language, with basic and applied parts for each subject. Student performance is measured by the percentage of correct answers in each category, and performance data are available for each prefecture ${ }^{2}$. The average percentages for 2009 are reported in Table $1^{3}$. This paper attempts to investigate how social trust affects percentages of correct answers on these tests to examine the effect of social trust on student performance.

\footnotetext{
${ }^{1}$ Anderson (2008) found that various proxies for social capital are positively associated with achievement test scores. However, Anderson did not explore the effect of social trust on test scores. ${ }_{2}$ A Japanese prefecture is roughly the equivalent of a state in the United States or a province in Canada.

${ }^{3}$ Tests were conducted in 47 prefectures; thus, there are 47 observations for each category.
} 


\section{Data and Model}

Table 2 includes variable definitions and a summary of statistics. The dependent variable was percentage of correct answers on the 2009 achievement tests in Japan. To construct a proxy for social trust, this paper used data from the Japanese General Social Surveys (JGSS) which were conducted between 2000 and 2003. The JGSS included the following question: "Generally speaking, would you say that most people can be trusted?" There were three choices for respondents: "Yes", "Depends", and "No". To measure the degree of social trust, I quantified the choices "Yes", "Depends", and "No" as 3, 2, and 1, respectively. In addition, I calculated the average value of social trust within a prefecture and used it as a proxy for social trust. This was the definition of TRUST ${ }^{4}$

The independent variables are discussed below. The estimated function takes the following form:

SCORE $_{\mathrm{i}}=\alpha_{0}+\alpha_{1}$ TRUST $_{\mathrm{i}}+\alpha_{2}$ GINI $_{\mathrm{i}}+\alpha_{3}$ HC $_{\mathrm{i}}+\alpha_{4}$ INCOM $_{\mathrm{I}}+\alpha_{5}$ SPEDU $_{\mathrm{i}}+\alpha_{6}$ MATH $_{\mathrm{i}}+\alpha_{7}$ $\mathrm{BASIC}_{\mathrm{i}}+\varepsilon_{\mathrm{i}}$ where the dependent variable in prefecture $\mathrm{i}$ is achievement test scores. The regression parameter is represented by $\alpha$ which can be interpreted as elasticity with the exception of dummies ${ }^{5} ; \varepsilon_{\mathrm{i}}$ represents the error term. If social trust improves test scores, TRUST will take the positive sign. Consistent with previous research (Bjørnskov 2009; Papagapitos and Riley 2009), other control variables including GINI, HC, INCOM and SPEDU are incorporated to capture economic factors.

\footnotetext{
${ }^{4}$ It is unclear if "Depends" can be considered an intermediate category. This response choice may have been selected by a number of respondents who would have answered differently if other possible responses had been included in the questionnaire. To alleviate any bias arising from this, I used a dummy which takes 1 if the response is "Yes", otherwise 0, excluding "Depends" from the sample as a dependent variable. I obtained similar results from the estimation using this dummy as social trust. However, to save space, these results were not reported. They are available upon request.

${ }^{5}$ See more details in Greene (1997, p. 280).
} 
MATH and BASIC control for subject and question category, respectively ${ }^{6}$.

This paper examined the effect of social trust on human capital formation. Conversely, human capital appears to influence social trust (Huang, van den Brink, and Groot 2009). The direction of causality is thus ambiguous, resulting in endogeneity bias. Hence, I used the GMM 2SLS method to control for this bias. This paper follows the work of Bjørnskov (2009), who used a measure of absence of corruption as an instrumental variable for social trust when investigating human capital growth. The disclosure of official information enables citizens to keep a close eye on corruption, thus resulting in a reduction in corruption. Since the 1990s, official information has been disclosed when citizens request it $^{7}$. Enactment of official information ordinances is considered to be positively related to the relative absence of corruption. Hence, the rate ${ }^{8}$ of towns and villages that had issued the disclosure of official information ordinance (OINF) was used as an instrumental variable. This rate was calculated for each prefecture.

Apart from OINF, this paper used additional instrumental variables. People seem to trust each other if there is a place where they can communicate with each other. Yamamura (2008) found that the number of community centers is positively related to trust in Japan. Therefore, number of community centers (CCENT) was used as an instrumental variable. Not meeting with friends (NOFRD) was also used as an instrumental variable. One question included in the JGSS was "How often do you meet or dine with friends?" There were 7 choices for respondents from 1 (Almost every day) to 7 (Never). NOFRD was the rate of "Never" for each prefecture.

\footnotetext{
6 This paper used values of independent variables in 2004 to alleviate endogeneity bias.

${ }^{7}$ Here, official information is considered information such as official documents, which the local government retained and has not disclosed.

${ }^{8}$ This rate is measured as (number of towns and villages that have issued the disclosure of official information ordinance) / (total number of towns and villages).
} 


\section{Results}

In the interest of brevity, I focused on results for TRUST. The sample size was small. Therefore, the jackknife method was used to calculate the standard error to make sure that results were not spurious. TRUST yielded the positive sign in all estimations. As reported in columns (1) and (2) of Table 3, results of the OLS model suggested that junior high school was statistically significant, but primary school was not significant. Regarding the GMM 2SLS model shown in columns (3) and (4) of Table 3, results of the over-identification test did not reject the null hypothesis that TRUST is exogenous for primary and junior high school estimation. TRUST was statistically significant for not only junior high school but also for primary school. Furthermore, the value of the primary school coefficient was 0.92 , which was larger than that for junior high school. This suggests that the effect of social trust was greater on test scores of primary school students than on scores of junior high school students. These results imply that social trust has a greater role in improving performance of students in an early stage of education compared with a later stage.

\section{Conclusions}

This study explored how social trust affects achievement test scores, using prefecture level data of Japan. Major findings indicate that social trust improves language and mathematics achievement scores for primary and junior high school students. After controlling for endogeneity bias, the effect of social trust was greater on primary school scores than on junior high school scores. 


\section{References}

Anderson, J.B. 2008. Social capital and student learning: Empirical results from Latin American primary schools. Economics of Education Review 27, 439-449.

Asahishimbun. 2008. Minryoku (CD-ROM version). Tyokyo: Asahishimbun-sha.

Bjørnskov, C. 2006. The multiple facets of social capital. European Journal of Political Economy $22,22-40$.

Bjørnskov, C., 2009. Social trust and the growth of schooling. Economics of Education Review. 28, 249-257.

Coleman, J. 1998. Social capital in the creation of human capital. American Journal of Sociology 98, S95-120.

Greene, W.H. 1997. Econometric Analysis (3rd ed.). London, Prentice-Hall.

Huang, J., van den Brink, H.M., Groot, W. 2009. A meta-analysis of the effect of education on social capital. Economics of Education Review 28, 454-464

Knack, S., Keefer, P. 1997. Does social capital have an economic payoff? A cross-country investigation. Quarterly Journal of Economics 112, 1251-1288.

Paldam, M. 2000. Social capital: one or many? Definition and measurement. Journal of Economic Survey 14, 629-653.

Papagapitos, A., Riley, R., 2009. Social trust and human capital formation. Economics Letters 102 , 158-160

Putnam, R. 2000. Bowling alone: The collapse and revival of American community. New York, Simon and Schuster.

Yamamura, E. 2008. Determinants of trust in a racially homogeneous society. Economics Bulletin $26(1), 1-9$. 
Table 1. Percentage of correct answers on achievement tests

(1) Primary school

\begin{tabular}{|c|c|c|c|c|}
\hline & \multicolumn{2}{|c|}{ Mathematics } & \multicolumn{2}{|c|}{ Japanese language } \\
\hline & Basic & Applied & Basic & Applied \\
\hline Score & 79.1 & 54.4 & 70.2 & 50.7 \\
\hline Observations & 47 & 47 & 47 & 47 \\
\hline \multicolumn{5}{|c|}{ (2) Junior high school } \\
\hline & \multicolumn{2}{|c|}{ Mathematics } & \multicolumn{2}{|c|}{ Japanese language } \\
\hline & Basic & Applied & Basic & Applied \\
\hline Score & 63.1 & 57.3 & 77.6 & 75.2 \\
\hline Observations & 47 & 47 & 47 & 47 \\
\hline
\end{tabular}


Table 2. Variable definitions and basic statistics

\begin{tabular}{|c|c|c|c|c|c|}
\hline Variable & Definition & Mean & $\begin{array}{l}\text { Standard } \\
\text { deviation }\end{array}$ & Max & Min \\
\hline TRUST & $\begin{array}{l}\text { Average value of the degree of generalized trust }(1=\text { No, } 2=\text { Depends, } \\
3=\text { Yes). }\end{array}$ & 2.08 & 0.06 & 2.19 & 1.95 \\
\hline GINI & Gini coefficient of income. & 0.30 & 0.01 & 0.34 & 0.27 \\
\hline $\mathrm{HC}$ & Percentage of the population who were university graduates $(\%)$. & 9.8 & 3.1 & 21.9 & 5.5 \\
\hline INCOM & Per capita income (thousands of yen). & 2765 & 376 & 4376 & 2074 \\
\hline SPEDU & Expenditure on students per capita (thousands of yen). & 105.8 & 16.9 & 154.3 & 71.3 \\
\hline MATH & This takes 1 if the observation is for mathematics, otherwise 0 . & --- & --- & --- & --- \\
\hline BASIC & This takes 1 if the observation is a basic question, otherwise 0 . & --- & --- & --- & --- \\
\hline OINF & $\begin{array}{l}\text { Rate of towns and villages that had issued the disclosure of official } \\
\text { information ordinance }(\%) \text {. }\end{array}$ & 90.0 & 10.1 & 100 & 53.8 \\
\hline NOFRD & Rate of respondents who never meet or dine with friends. & 9.88 & 2.89 & 18.6 & 3.37 \\
\hline CCENT & Number of community centers per population (population in thousands). & 0.22 & 0.17 & 0.90 & 0.07 \\
\hline
\end{tabular}


Table 3. Dependent variable: Test scores

\begin{tabular}{|c|c|c|c|c|}
\hline Variable & $\begin{array}{l}(1) \\
\text { OLS } \\
\text { Primary school }\end{array}$ & $\begin{array}{c}\text { (2) } \\
\text { OLS } \\
\text { Junior high school }\end{array}$ & $\begin{array}{l}\text { (3) } \\
\text { GMM 2SLS } \\
\text { Primary school }\end{array}$ & $\begin{array}{c}(4) \\
\text { GMM 2SLS } \\
\text { Junior high school }\end{array}$ \\
\hline TRUST & $\begin{array}{l}0.10 \\
(0.89)\end{array}$ & $\begin{array}{l}0.20^{*} \\
(1.70)\end{array}$ & $\begin{array}{l}0.92 * \\
(2.02)\end{array}$ & $\begin{array}{l}0.79^{*} \\
(1.94)\end{array}$ \\
\hline GINI & $\begin{array}{l}-0.10 \\
(-1.44)\end{array}$ & $\begin{array}{l}-0.31 * * * \\
(-3.43)\end{array}$ & $\begin{array}{l}-0.12^{*} \\
(-1.66)\end{array}$ & $\begin{array}{l}-0.32 * * * \\
(-3.41)\end{array}$ \\
\hline $\mathrm{HC}$ & $\begin{array}{l}0.02 * * \\
(2.04)\end{array}$ & $\begin{array}{l}-0.04 * * * \\
(-3.29)\end{array}$ & $\begin{array}{l}0.05^{* * * *} \\
(2.61)\end{array}$ & $\begin{array}{l}-0.02 \\
(-1.26)\end{array}$ \\
\hline INCOM & $\begin{array}{l}0.02 \\
(0.83)\end{array}$ & $\begin{array}{l}0.11 * * * \\
(3.79)\end{array}$ & $\begin{array}{l}-0.04 \\
(-1.24)\end{array}$ & $\begin{array}{l}0.05 \\
(1.29)\end{array}$ \\
\hline SPEDU & $\begin{array}{l}0.05^{*} \\
(1.90)\end{array}$ & $\begin{array}{l}0.01 \\
(0.53)\end{array}$ & $\begin{array}{l}0.08 * * * \\
(2.61)\end{array}$ & $\begin{array}{l}0.03 \\
(1.19)\end{array}$ \\
\hline MATH & $\begin{array}{l}6.29 * * * \\
(16.1)\end{array}$ & $\begin{array}{l}-16.2 * * * \\
(-40.8)\end{array}$ & $\begin{array}{l}6.29 * * * \\
(13.8)\end{array}$ & $\begin{array}{l}-16.2 * * * \\
(-36.9)\end{array}$ \\
\hline BASIC & $\begin{array}{l}22.0 * * * \\
(56.4)\end{array}$ & $\begin{array}{l}4.05 * * * \\
(10.1)\end{array}$ & $\begin{array}{l}22.0 * * * * \\
(48.3)\end{array}$ & $\begin{array}{l}4.00 * * * \\
(9.22)\end{array}$ \\
\hline Constant & $\begin{array}{l}43.0^{* * * *} \\
(4.53)\end{array}$ & $\begin{array}{l}76.2^{* * * *} \\
(7.56)\end{array}$ & $\begin{array}{l}-6.61 \\
(-0.22) \\
\end{array}$ & $\begin{array}{l}37.6 \\
(1.44) \\
\end{array}$ \\
\hline $\begin{array}{l}\text { Hansen's J } \\
\text { statistics } \\
\text { Observations }\end{array}$ & 188 & 188 & $\begin{array}{l}1.14 \\
P=0.56 \\
188\end{array}$ & $\begin{array}{l}2.24 \\
P=0.32 \\
188\end{array}$ \\
\hline
\end{tabular}

Note. With the exception of the constant and dummies such as MATH and BASIC, values are elasticity evaluated at the sample means (Greene, 1997, pp. 278-280).. Values in parentheses are t-statistics calculated by standard errors obtained using the jackknife method. $* * *, * *$ and $*$ denote significance at the $1 \%, 5 \%$ and $10 \%$ level, respectively. 